Research Article

\section{Pig raising practices by unprivileged, ethnic people in Bangladesh}

\author{
Ausraful Islam*, Ashika Akbar Trisha ${ }^{2}$, Md. Safiul \\ Ahad Sardar ${ }^{2}$, Mohammady Akbor ${ }^{3}$, Abdulla Al Mamun \\ Bhuyan $^{4}$, Md. Sazzad Hossain ${ }^{4}$, Md. Ashraf Zaman Faruk ${ }^{4}$, \\ Sheikh Muhammad Khaled Sharif ${ }^{5}$, Zannatun Nahar ${ }^{5}$ and \\ Anisuzzaman ${ }^{6}$
}

\author{
${ }^{1}$ Programme for Emerging Infections, Infectious Diseases Division, ICDDR, Bangladesh \\ ${ }^{2}$ Department of Livestock Services, Government of Bangladesh, Bangladesh \\ ${ }^{3}$ The Hong Kong Polytechnic University, Hong Kong \\ ${ }^{4}$ Department of Veterinary Science, University of Rajshahi, Rajshahi, Bangladesh \\ ${ }^{5}$ Food and Agriculture Organization, Bangladesh, Faculty of Veterinary Science, Bangladesh \\ ${ }^{6}$ Bangladesh Agricultural University, Mymensingh, Bangladesh
}

\begin{abstract}
More Information
*Address for Correspondence: Dr. Ausraful Islam Room 3029, IPH Building, 68, Shaheed Tajuddin Ahmed Sarani, Mohakhali, Dhaka-1212, Bangladesh, Tel: +8801716193200; Email: rajibdvmpara@gmail.com; islam_ausraf@icddrb.org

Submitted: December 17, 2020

Approved: January 14, 2021

Published: January 15, 2021

How to cite this article: Islam A, Trisha AA, Sardar MSA, Akbor M, Bhuyan AA, et al. Pig raising practices by unprivileged, ethnic people in Bangladesh. Insights Vet Sci. 2021; 5: 001-007.

DOI: 10.29328/journal.ivs.1001028

ORCiD: orcid.org/0000-0001-9608-0823

Copyright: (c) 2021 Islam A, et al. This is an open access article distributed under the Creative Commons Attribution License, which permits unrestricted use, distribution, and reproduction in any medium, provided the original work is properly cited.
\end{abstract}

Keywords: Swine; Pig raisers; Poverty; Zoonotic diseases

Check for updates

OPEN ACCESS

\begin{abstract}
We interviewed 207 pig raisers from seven different districts of Bangladesh to explore their practices related to their pig farming. We used structured questionnaires to interview the pig raisers and used descriptive statistics for analysis. Most of the pig raisers $(54 \%)$ were illiterate. $50 \%$ (104) of them had a monthly income of less than 10000 BDT and $60 \%(124)$ were landless. Most of the pig raisers $(92 \%, 191)$ were rearing local breed and $67 \%$ of them were practicing semi-scavenging system. As feed source $55 \%$ (114) pig owners used kitchen waste and $54 \%$ (111) used rice husk. The pig raisers mentioned different types of challenges such as social problem $(16 \%)$, disease $(50 \%)$, less profitable $(20 \%)$ and unavailability of feed $(19 \%)$. In our study, we found that $31 \%$ respondents visited veterinarians, $28 \%$ visited quack and $21 \%$ do not take any action when their pigs were sick. Only $16 \%$ pig raisers used vaccines against different infectious diseases and $36 \%$ used anthelmintics against parasitic diseases. Awareness buildup of the pig raisers may help them raising pigs in a better way which will improve the farming system and reduce the probability of disease transmission.
\end{abstract}

\section{Introduction}

Pigs are highly prolific animals compared to other farm animals [1]. Genetically pigs are two times more efficient than ruminants in converting feed to meat [2]. Pork is considered as the richest animal protein source. But pig production in Bangladesh is influenced by cultural and religious beliefs or taboos. As a result, only non-Muslim minority people raise pigs in Bangladesh. The estimated pig population reared in the household of Bangladesh is 326,000 which are raised by Christians, ethnic people, lower caste Hindus/sweepers [3]. Bangladesh's minority ethnic population is $2 \%$ of the total and they inhabit in both plain lands and hilly areas $[4,5]$ and markedly different interms of social, cultural and development status from majority group, the "Bengali" [6,7]. At present, there are about 3.5 to 5.5 million sweepers in 63 different districts of Bangladesh are ultra-poor with limited access to health, education and employment opportunities.
In Bangladesh, pigs are mostly reared in semi-scavenging system to maximize the output by employing minimum inputs such as feed, medication, time and effort but increases the interaction among pigs, environment and humans, and favors the transmission of different zoonotic diseases through direct contact or environmental contamination [8]. In Bangladesh, pigs were detected as a host of different viral, bacterial and parasitic diseases [9-15]. Several management issues such as feeding, breeding, disease prevalence, marketing and constraints of pig production are not well reported from Bangladesh. An earlier study has reported that balanced feed was not supplied to pigs, veterinary service was not available in most cases, piglets died frequently and and pigs were suffering from different diseases [16].

We conducted this study to better understand the management system of pigs in Bangladesh. In addition, our data might be useful for future research and developing intervention in this sector. 


\section{Materials and methods}

We conducted this study in seven districts of Bangladesh: Rangamati, Dinajpur, Rajshahi, Mymensingh, Meherpur, Kishorgonj and Natore (Figure 1). We purposively selected these sites for the convenience of the study to understand pig raising practices both on hilly areas and plain lands and by pig raisers of different ethnic group. We assumed $85 \%$ pig raisers would provide houses to their pigs [17]. Considering 95\% confidence interval, $85 \%$ expected prevalence and 5\% precision our calculated sample size is 196 pig raisers. In Rangamati, Dinajpur and Rajshahi pig raisers were tribal people and in rest of the places pig raisers were lower caste Hindus. Rangamati located at the southern part of Bangladesh and is a hilly area. Rest of the places are plain land and geographically identical. We used structured questionnaires to interview the pig raisers. Variable investigated included demographic information of pig owners, number of pigs by households, management practices, source of feed and water, cost of feed per pig, signs of disease of pigs and other livestock owned by the pig owners. For the convenience of the analysis we grouped all the respondents' udder two groups: tribal community and sweeper colony. Descriptive statistics such as percentages and frequency tables were prepared from the data generated. Chi-square test was used to test the significance of the associations between different parameters, and were applicable Fishers exact test was used.

\section{Results}

We interviewed a total of 207 pig raisers from was from Rangamati district $(64,31 \%)$, Dinajpur district $(45,22 \%)$, Mymensingh district (32, 15\%), Rajshahi district (25, 12\%), Natore district (22,11\%), Kishorgonj district (11,5\%) and Meherpur district $(8,4 \%)$. We grouped the respondents from Rangamati, Dinajpur and Rajshahi under tribal community (119) and respondents from Mymensingh, Meherpur, Kishorgoj and Natroe under sweeper colony (88). Most of the pig raisers enrolled in this study were Hindus (58\%) followed by Buddhist (28\%), Sonaton (17\%) and Christians (6\%). Most

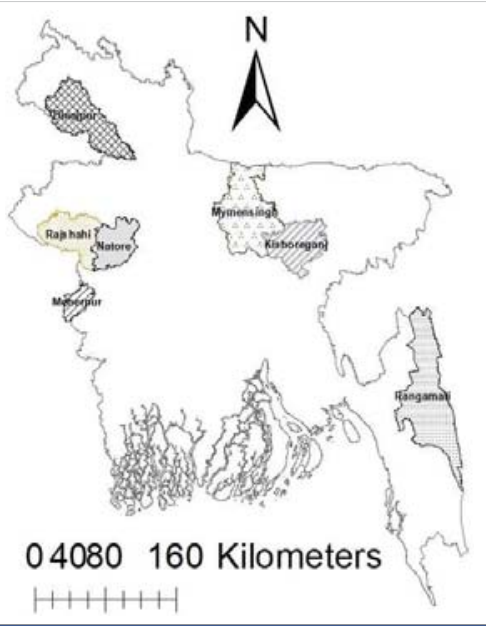

Figure 1: Study sites: showing six districts in different parts of Bangladesh. of the pig raising family (54\%) had 5-8 (Median 5) family members. Most of the pig raisers (54\%) were illiterate and $43 \%$ had education below SSC (Secondary School Certificate; grade X) level. Among our interviewee 57\% (119) were from tribal community and $43 \%$ (88) from sweeper colony. Median age of the pig raisers was 37 years. We found various types of profession among the pig raisers: $41 \%$ (85) were daily wager and $22 \%$ (41) were involved in agriculture, and 50\% (104) of them had a monthly income of less than 118 USD and 36\% had less than 59 USD. Most of them $(60 \%, 124)$ were landless and $22 \%$ (46) of them owned land ranged from 1-20 decimal (Table 1).

Most of the pig raisers from both tribal community and sweeper colony $(92 \%, 191)$ were rearing local breed $(p<$ $0.001)$. Semi-scavenging system $(p<0.001)$ was practiced

Table 1: Demographic parameters of pig farmers surveyed in different districts of Bangladesh.

\begin{tabular}{|c|c|c|c|}
\hline \multicolumn{2}{|c|}{ Parameters } & \multirow{2}{*}{$\begin{array}{c}\text { Numbers (207) } \\
64\end{array}$} & \multirow{2}{*}{$\begin{array}{c}\% \\
1\end{array}$} \\
\hline Districts & Rangamati & & \\
\hline & Mymensingh & 32 & 15 \\
\hline & Meherpur & 8 & 4 \\
\hline & Dinajpur & 45 & 22 \\
\hline & Kishorgonj & 11 & 5 \\
\hline & Rajshahi & 25 & 12 \\
\hline & Natore & 22 & 11 \\
\hline \multirow[t]{7}{*}{ Age } & $15-25$ & 35 & 17 \\
\hline & $25-35$ & 68 & 33 \\
\hline & $35-45$ & 43 & 21 \\
\hline & $45-55$ & 39 & 19 \\
\hline & $55-65$ & 17 & 8 \\
\hline & $65>$ & 5 & 2 \\
\hline & Median & 37 & \\
\hline \multirow[t]{4}{*}{ Religion } & Hindu & 120 & 58 \\
\hline & Christians & 13 & 6 \\
\hline & Buddhist & 57 & 28 \\
\hline & Sonaton & 17 & 8 \\
\hline \multirow[t]{4}{*}{ Family members } & $1-4$ & 77 & 37 \\
\hline & $5-8$ & 111 & 54 \\
\hline & $9-16$ & 19 & 9 \\
\hline & Median & 5 & \\
\hline \multirow[t]{4}{*}{ Education level } & Illiterate & 111 & 54 \\
\hline & Below SSC & 88 & 43 \\
\hline & Below HSC & 6 & 3 \\
\hline & University & 2 & 1 \\
\hline \multirow[t]{2}{*}{ Community } & Tribal community & 119 & 57 \\
\hline & Sweeper colony & 88 & 43 \\
\hline \multirow[t]{6}{*}{ Profession } & Agriculture & 45 & 22 \\
\hline & Daily wager & 85 & 41 \\
\hline & Businessman & 23 & 11 \\
\hline & Sweeper & 32 & 15 \\
\hline & Private job & 9 & 4 \\
\hline & Other & 13 & 6 \\
\hline \multirow[t]{4}{*}{ Monthly income } & Less than 59 USD* & 75 & 36 \\
\hline & Less than 118 USD & 104 & 50 \\
\hline & Less than 235 USD & 25 & 12 \\
\hline & No answer & 3 & 2 \\
\hline \multirow[t]{5}{*}{ Size of land (decimal) } & 0 & 124 & 60 \\
\hline & $1-20$ & 46 & 22 \\
\hline & $21-40$ & 1 & 0.50 \\
\hline & $41-60$ & 1 & 0.50 \\
\hline & 61 and above & 35 & 17 \\
\hline
\end{tabular}

*USD: United States Dollars, 1 Dollar: 85 Taka 
by the most of the respondents from both communities $(139,67 \%)$. Purpose of raising pigs differed $p<0.05)$ and $71 \%$ (147) pig raisers were keeping pigs for business and own consumption, and $21 \%$ only for business. Very few respondents $(8,4 \%)$ received training $(p<0.05)$ on pig raising. Different members of the family were involved in taking care of the pigs $(p<0.001)$ and in most cases $(65 \%, 134)$ all family members were involved in talking care of the pigs followed by wives $(22 \%, 45)$ and husbands $(9 \%, 18)$. Spending time for taking care of pigs varied $(p<0.001)$ and $40 \%$ (83) pig raisers were spending two hours for taking care of the pigs, followed by $28 \%$ (57) for one hour and 33\% (67) for three hours or more. Most $(177,86 \%)$ pig raisers mentioned that they provide houses $(p<0.002)$ for the pigs which were very close to their own house. Pig raisers from both community used different materials for making houses for pig $(p<0.001)$ and most of them $(49 \%, 102)$ used bamboo to make shelter for pigs where as $16 \%$ (34) each used brick and mud respectively. In our study, 78\% (161) respondents did not do anything about the pig excreta $(p<0.001)$, whereas $13 \%$ (26) either buried the excreta or used it as fertilizer. Most $(92 \%, 191)$ of the pig raisers bought and collected feed for their pigs. Most $(93 \%, 192)$ of the pig raisers were providing feed to their pigs three times a day. As feed cost, most of the pig raisers from both communities $(92 \%, 191)$ pig raisers were spending 0.01 $0.59 \mathrm{USD} / \mathrm{pig} /$ day and $6 \%$ (12) were spending > $0.58 \mathrm{USD} /$ pig/day ( $p<0.001)$. As feed source 55\% (114) pig owners used kitchen waste $(p<0.001), 54 \%$ (111) used rice husk $(p<0.001), 54 \%$ (101) used wheat $(p<0.001)$, rice and maize bran ( $p<0.001), 45 \%$ (94) used rice ( $p<0.001), 35 \%$ (73) used arum $(p<0.001)$ and $28 \%$ used local wine $(p<0.001)$. Pig raisers used different types of water sources for their pigs $(p<0.001)$ and more than half of them $(57 \%, 119)$ used tube well, 20\% (41) used river and 18\% (37) used pond. We recorded that $71 \%$ (146) farmers killed pig $(p<0.001)$ anytime of the year where as $19 \%$ (61) only during festival. Method of killing pig also varied ( $p<0.001)$ : 41\% used spear through the heart to kill the pigs, 34\% separated the head directly and $22 \%$ stroke at the head. $85 \%$ pig raisers mentioned that they comsume raw blood of pigs (Table 2).

Sources of piglets were different for both communities ( $p<0.001$ ): 33\% (68) pig raisers bred their pigs and $56 \%$ respondents were collecting piglets from markets, $20 \%$ from neighbors and $17 \%$ from middlemen. In most cases $(86,42 \%)$ the price $(p<0.001)$ of piglets was $12-24$ USD. We observed that $81 \%$ (167) pig raisers kept $1-4$ boars, 56\% (115) kept $1-4$ sows and $26 \%$ kept $1-4$ piglets. We found that $87 \%$ pig owners sell adult pigs $(p<0.001)$ and price $(p<0.05)$ varied from 59-176 USD (Table 3).

The pig raisers from both communities mentioned different types of challenges such as social problem $(16 \%$, $p<0.05)$, disease $(50 \%, p<0.01)$, less profitable $(20 \%$, $p<0.001$ ) and unavailability of feed (19\%) (Table 4). In our study, we found that $31 \%$ respondents visited veterinarians,
$28 \%$ visited quack and $21 \%$ do not take any action when their pigs were sick. Only $16 \%$ pig raisers used vaccines against different infectious diseases and 36\% used anthelmintics against parasitic diseases. Pig raisers informed that most of the diseases occur during summer and rainy season (Table 5). During our studies, 85\% respondents reported different signs of illness among their pigs. 46\% reported anorexia, $28 \%$ reported gastrointestinal disorders, $28 \%$ reported fever, $27 \%$ reported respiratory distress, $12 \%$ reported swollen jaw, $12 \%$ reported inflamed hoof, $11 \%$ reported sudden death and $5 \%$ reported joint ill (Figure 2). We found that 29\% pig raisers had goats, $29 \%$ had chickens, $22 \%$ had cows, $7 \%$ had ducks and 6\% had dogs (Figure 3).

\section{Discussion}

None of the respondents, unlike other countries, took pig raising as only source of their income; rather pig raising was their additional way of earning. Lack of land and poverty could be the reasons behind this. Similar practice was observed in Phillipines and Ehiopia [18,19]. More than half of the pig raisers were illiterate. Such poor literacy level limited their opportunity to obtain a job in private or government offices. As a result, all of them were involved in different low income jobs, conforming to the observations reported worldwide including Bangladesh $[18,20]$. Illiteracy is one of the constrains of pig industry since studies have shown that educated pig raisers can make more profit than the uneducated ones [21,22]. Two third of the pig raisers were landless. As a result, these landless pig raisers face vulnerability of livelihood and economic opportunities which force them to engage in different low income jobs, and lead very substandard life in terms of food, housing, education and health facilities and exactly similar situations have been reported from earlier studies [16,20,23], indicating there receding, traditional and stagnant livelihood.

We have seen that almost all the pig raisers were raising local breed mostly in semi-scavenging system. Indigenous pigs are more disease resistant, produce more tasty meat, and have a satisfactory survival rate $[23,24]$. In semi-scavenging system the owner provide a partial feed and the pigs search for the rest from the environment. This system was practiced obviously due to lower supply of inputs or to maximize the profit margin, and such type of orthodox system of pig rearing had also been reported in an earlier study from Bangladesh [8], clearly indicating no or very minimum improvement in their knowledge about modern and sophisticated pig farming. Furthermore, these types of rearing systems have significant public health importance. Poor housing with open defecation and presence of free range pigs were identified as risk factors for transmission of Taenia solium-taeniasis to pig raisers from different countries [25-28]. The family members took care of pigs probably due to their poverty, small farm size and to make more profit. Raising pigs by the family members was observed by earlier researchers from Bangladesh [8,23], suggesting that they are equally at risk to the pig-borne deadly 
diseases. Pigs can remain as reservoir for zoonotic influenza virus like H3N2 and H1N1 long time, which can later infect humans $[29,30]$. Pig houses were closely located to the houses of the owners, conforming to the pig housing reported from India and Nepal $[25,26]$. Pig houses were made by different locally available materials which were also observed in other countries including Bangladesh before [16,31-33]. Most of the pig raisers were not disposing off the excreta in a specific place. A previous study from Bangladesh has reported the similar observation where pig raisers were unconcerned and did not take any action for proper disposal of the waste [8]. Most of the pig raisers were providing feed to their pigs three times a day. Similar type of feeding frequency was observed in other pig raising communities [31,33]. Cost of feed and type of feed varied but more than half of the pig raisers used kitchen waste as feed. The pig raisers collected kitchen waste

Table 2: Different parameters of pig management in the study area. Number and proportion are presented

\begin{tabular}{|c|c|c|c|c|c|c|}
\hline \multicolumn{2}{|c|}{ Parameters } & Tribal commnity & Sweeper colony & Numbers (207) & $\%$ & $p$ - value \\
\hline \multirow[t]{2}{*}{ Breed } & Local & 102 & 88 & 191 & 92 & \multirow{2}{*}{0.001} \\
\hline & Others (Land race, Cross, Indian) & 17 & 0 & 16 & 8 & \\
\hline \multirow{3}{*}{ Type of rearing } & Scavenging & 5 & 8 & 13 & 6 & \multirow{3}{*}{0.001} \\
\hline & Semi-scavenging & 106 & 33 & 139 & 67 & \\
\hline & Intensive & 8 & 47 & 55 & 27 & \\
\hline \multirow{4}{*}{ Purpose of rearing } & Business & 31 & 12 & 43 & 21 & \multirow{4}{*}{0.033} \\
\hline & Own consumption & 1 & 10 & 11 & 5 & \\
\hline & Business and own consumption & 81 & 66 & 147 & 71 & \\
\hline & Others & 4 & 0 & 4 & 2 & \\
\hline Training & Yes & 8 & 0 & 8 & 4 & 0.022 \\
\hline \multirow{4}{*}{ Caretaker } & Husband & 5 & 13 & 18 & 9 & \multirow{4}{*}{0.001} \\
\hline & Wife & 30 & 15 & 45 & 22 & \\
\hline & All family members & 82 & 52 & 134 & 65 & \\
\hline & Others (Grand children, Children, Servent) & 2 & 7 & 9 & 4 & \\
\hline \multirow{3}{*}{ Time spent for taking care } & 1 hour & 50 & 7 & 57 & 28 & \multirow{3}{*}{0.001} \\
\hline & 2 hours & 58 & 25 & 83 & 40 & \\
\hline & 3 hours or more & 11 & 56 & 67 & 33 & \\
\hline Separate house & Yes & 94 & 83 & 177 & 86 & 0.002 \\
\hline \multirow{4}{*}{ Material of pig house } & Brick & 0 & 34 & 34 & 16 & \multirow{4}{*}{0.001} \\
\hline & Mud & 23 & 11 & 34 & 16 & \\
\hline & Bamboo & 67 & 35 & 102 & 49 & \\
\hline & Others (brick \& bamboo or brick \& tin) & 5 & 3 & 8 & 4 & \\
\hline \multirow{3}{*}{ Disposal of pig excreata } & Nothing & 111 & 50 & 161 & 78 & \multirow{3}{*}{0.001} \\
\hline & Burry or used as fertilizer & 8 & 18 & 26 & 13 & \\
\hline & Thrown away & 0 & 20 & 20 & 10 & \\
\hline \multirow{3}{*}{ Source of food } & Buy & 9 & 3 & 12 & 6 & \multirow{3}{*}{0.522} \\
\hline & Buy and collect & 108 & 83 & 191 & 92 & \\
\hline & Collect & 2 & 2 & 4 & 2 & \\
\hline \multirow{2}{*}{ Frequency of provided food } & Twice a day & 7 & 8 & 15 & 15 & \multirow{2}{*}{0.340} \\
\hline & Thrice a day & 112 & 80 & 192 & 93 & \\
\hline & Tube well & 68 & 51 & 119 & 57 & \\
\hline Source of water & Pond & 4 & 33 & 37 & 18 & $0 \cap 01$ \\
\hline Goure or vater & River & 41 & 0 & 41 & 20 & 0.001 \\
\hline & Others (lake and rice strach) & 4 & 0 & 10 & 5 & \\
\hline & 0 USD/pig/day & 2 & 3 & 5 & 2 & \\
\hline Cost of food/pig/day & 0.01-0.59 USD/pig/day & 116 & 74 & 190 & 92 & 0.001 \\
\hline & 0.58 USD>/pig/day & 1 & 11 & 12 & 6 & \\
\hline & Kitchen waste & 45 & 69 & 114 & 55 & 0.001 \\
\hline & Local wine & 53 & 4 & 57 & 28 & 0.001 \\
\hline & Rice & 47 & 47 & 94 & 45 & 0.050 \\
\hline Types of food provided to the pigs & Wheat, rice and maize bran & 47 & 65 & 112 & 54 & 0.001 \\
\hline & Rice husk & 46 & 65 & 111 & 54 & 0.001 \\
\hline & Bamboo shoot & 42 & 5 & 47 & 23 & 0.001 \\
\hline & Arum & 55 & 18 & 73 & 35 & 0.001 \\
\hline Killing nigs for consumntion & Festival & 9 & 52 & 61 & 19 & 0001 \\
\hline 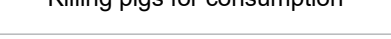 & Any time of year & 110 & 36 & 146 & 71 & 0.001 \\
\hline & Slaughter & 6 & 1 & 7 & 3.4 & \\
\hline How the pias are killed & Spear through the heart & 9 & 76 & 85 & 41 & 0.001 \\
\hline & Separate the head directly & 59 & 11 & 70 & 33 & \\
\hline & Strike in the head & 45 & 0 & 45 & 21 & \\
\hline Consumption of pig blood & Yes & 51 & 34 & 85 & 41 & 0.570 \\
\hline Wav of consumntion & With curry & 51 & 33 & 84 & 41 & 0195 \\
\hline vady of conisumiption & Raw with puffed rice and or curry & 0 & 3 & 3 & 2 & 0.195 \\
\hline
\end{tabular}


Table 3: Breeding and selling practices of pigs in the study area. Number and proportion are presented. Parameters Tribal commnity

\begin{tabular}{|c|c|c|c|c|c|c|}
\hline Param & & Tribal commnity & Sweeper colony & Numbers (207) & $\%$ & $p$ - value \\
\hline \multirow{6}{*}{ Source of piglets } & Neighbour & 18 & 23 & 41 & 20 & 0.001 \\
\hline & Middleman & 30 & 6 & 36 & 17 & \\
\hline & Market & 62 & 53 & 115 & 56 & \\
\hline & Scavenging herd & 1 & 3 & 4 & 2 & \\
\hline & Breeding & 1 & 2 & 3 & 1 & \\
\hline & Rangamati pig farm & 8 & 0 & 8 & 4 & \\
\hline \multirow{4}{*}{ Price per piglet } & 12 USD & 51 & 7 & 58 & 29 & 0.001 \\
\hline & 12-24 USD & 51 & 35 & 86 & 42 & \\
\hline & $>24$ USD & 9 & 36 & 45 & 23 & \\
\hline & Total & & & 198 & 96 & \\
\hline Breeding of pigs & Yes & 39 & 29 & 68 & 33 & 1.000 \\
\hline \multirow{5}{*}{ Number of boar in the farm } & 0 & 12 & 13 & 25 & 12 & 0.007 \\
\hline & $1-4$ & 104 & 63 & 167 & 81 & \\
\hline & $5-8$ & 3 & 9 & 12 & 6 & \\
\hline & $9-12$ & 0 & 3 & 3 & 1 & \\
\hline & Mean & & & 2 & & \\
\hline \multirow{5}{*}{ Number of sow in the farm } & 0 & 55 & 30 & 85 & 41 & 0.153 \\
\hline & $1-4$ & 59 & 56 & 115 & 56 & \\
\hline & $5-8$ & 3 & 2 & 5 & 2 & \\
\hline & $9-12$ & 2 & 0 & 2 & 1 & \\
\hline & Mean & & & 1 & & \\
\hline \multirow{6}{*}{ Number of piglets in the farm } & 0 & 61 & 72 & 133 & 64 & 0.001 \\
\hline & $1-4$ & 42 & 12 & 54 & 26 & \\
\hline & $5-8$ & 10 & 1 & 11 & 5 & \\
\hline & $9-12$ & 4 & 2 & 6 & 3 & \\
\hline & $13-16$ & 2 & 1 & 3 & 1 & \\
\hline & Mean & & & 1 & & \\
\hline \multirow{5}{*}{ Number of total pigs in the farm } & $1-4$ & 83 & 46 & 129 & 62 & 0.008 \\
\hline & $5-8$ & 19 & 32 & 51 & 25 & \\
\hline & $9-12$ & 9 & 8 & 17 & 8 & \\
\hline & $13>$ & 8 & 2 & 10 & 4 & \\
\hline & Mean & & & 5 & & \\
\hline Sell adult pigs & Yes & 115 & 66 & 181 & 87 & 0.001 \\
\hline \multirow{4}{*}{ Price per adult pig } & 59 USD & 7 & 7 & 14 & 7 & 0.010 \\
\hline & 59-118 USD & 75 & 27 & 102 & 49 & \\
\hline & 118-176 USD & 11 & 14 & 25 & 12 & \\
\hline & 176 USD > & 2 & 3 & 5 & 2 & \\
\hline
\end{tabular}

USD: United States Dollars; 1 Dollar: 85 Taka

Table 4: Challenges of pig rearing reported by the owners in the study area. Number and proportion are presented

\begin{tabular}{|c|c|c|c|c|c|}
\hline Parameters & Tribal community & $\begin{array}{c}\text { Sweeper } \\
\text { colony }\end{array}$ & $\begin{array}{c}\text { Numbers } \\
\mathbf{( 2 0 7 )}\end{array}$ & $\boldsymbol{\%}$ - value \\
\hline Social problem & 12 & 21 & 33 & 16 & 0.012 \\
\hline Disease & 48 & 55 & 103 & 50 & 0.002 \\
\hline Not cost effective & 40 & 2 & 42 & 20 & 0.001 \\
\hline Food unavailable & 27 & 12 & 39 & 19 & 0.109 \\
\hline
\end{tabular}

Table 5: Disease management by the pig raisers in the study area. Number and proportion are presented.

\begin{tabular}{|c|c|c|c|}
\hline \multicolumn{2}{|c|}{ Parameters } & Number & $\%$ \\
\hline What is done when pig is sick & Quack & 50 & 28 \\
\hline & Veterinarian & 56 & 31 \\
\hline & Nothing & 38 & 21 \\
\hline & Sale at cheap price & 16 & 9 \\
\hline & Kill to eat & 3 & 2 \\
\hline Use of vaccine & Treated by the owner himself & 4 & 2 \\
\hline Use of anthelmintic & Yes & 29 & 16 \\
\hline When most of the disease occur & Yes & 64 & 36 \\
\hline & Shroughout the year & 55 & 31 \\
\hline & Rainy & 44 & 29 \\
\hline & Winter & 11 & 6 \\
\hline & Winter and rainy & 6 & 3 \\
\hline & Summer and winter & 3 & 2 \\
\hline & Summer and rainy & 2 & 1 \\
\hline
\end{tabular}

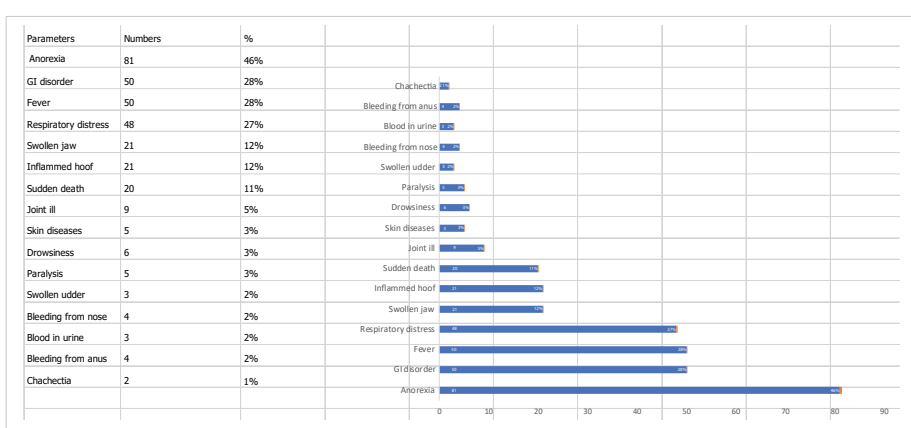

Figure 2: Different diseases reported by the owners in the study area.

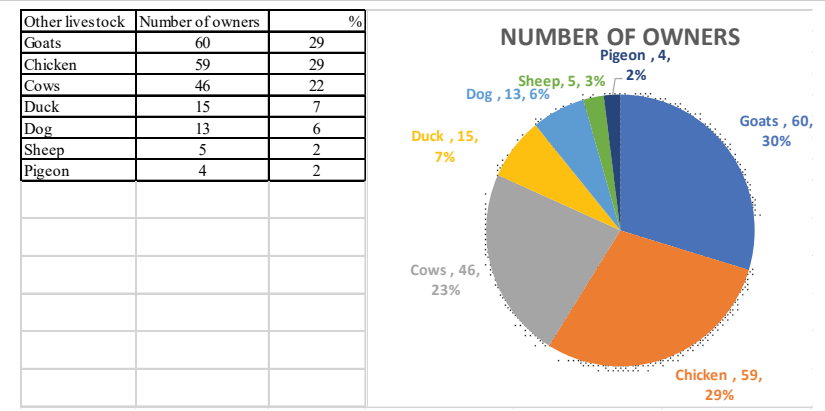

Figure 3: Other livestock owned by the study participants. 
from different restaurants either for free or at a very minimal price, which is commonly practiced in Bangladesh and India $[8,33]$. They used kitchen waste probably due its availability and very low price. As pigs are omnivorous animals, they are able to consume the kitchen waste which is a mixed up of rice, fish, meat and vegetables [34]. As pigs are consuming feed which would otherwise be wasted, they are actually keeping the environment clean. The pig raisers fed local wine to pigs as they believed that local wine will significantly increase the growth rate of the pigs. Pig raisers were found to use brewer's by-products as feed for pigs in Ethiopia [19]. Three pig raisers mentioned that they eat raw blood with puffed rice, which is potentially dangerous as a source of communicable diseases.

Only one third of the pig raisers were breeding their pigs and the rest were conllecting piglets from different sources among which market was the major one. A previous study from Bangladesh has shown that 93.33\% piglets were procured from local market [31]. Pig raisers choose markets probably due to availability of more piglets, option to choose and to get better a price. On an average there were five pigs at each farm, which indicate that pig farming in Bangladesh is mostly a small family owned industry. The contributing factors for such small scale farms could be lack of space, lack of capital, lack of food, mortality of piglets and other constrains including diseases [16].

The challenges mentioned by the pig raisers were in agreement to the findings from earlier studies [8,35]. A previous study has reported social disrespect to the pig raisers by majority Muslims as pig is regarded as unholy to the Muslim community [8]. Diseases of pigs are one of the challenges faced by the pig raisers and those signs of diseases were reported earlier [16,31,36]. Pig raisers did not take necessary steps to treat their animals. In our study, we found that only one third of them seek support from the veterinarians when their pigs were sick. Also, pig raisers were not fully aware of vaccines and anthelmintics which supports results from earlier studies $[16,19,31,35]$. Parasites including both ecto and endo parasites negatively affect the growth and feed efficiency of pigs. Several types of parasites of pigs has been reported from Bangladesh in the past: Haematopinus suis, Boophilus microplus, Fasciolopsis buski, Gastrodiscoides hominis, Ascaris suum, Metastrongylus elongatus, Stephanurus dentatus, Physocephalus sexalatus [15,37]. These parasitic disease can be treated easily with commercially available anthelmintics which will not only accelerate the growth rate of pigs, but also will minimize the risk of pig borne zoonoses $[38,39]$. Pigs are also infected by Foot and Mouth Disease, hemorrhagic septicemia and anthrax, which can be controlled by vaccines available in Bangladesh at a subsidized price. Pig raisers were keeping different types of animals together which is substantiated by an earlier study from Bangladesh [8] and pose the animals to the risk of communicable diseases $[40,41]$. Transmission of avian influenza virus from poultry to pig has been reported earlier [42-44].

\section{Conclusion}

Taken together, our study revealed that pig raisers had small farms in their backyard and reared pigs in traditional ways. Many pig raisers practiced semi-scavenging system to minimize the feed cost, which on the other hand can play role for transmitting disease from pig to humans. Additionally, lack of knowledge about proper disposal of pig excreta; close contact with pigs, co-farming, unconsciousness about proper hygiene, close housing with their own dwelling places are the main factors, so far assumed, associated with the spreading of communicable diseases. Initiative from different government and non-government organization to train and aware the pig raisers will not only increase production but also will minimize the transmission different pig-borne zoonoses, and ultimately will help the receding, ethnic, resource deprived, unprivileged segment of the population to uphold their livelihood.

\section{Acknowledgement}

ICDDR, B is thankful to the Governments of Bangladesh, Canada, Sweden and the UK for providing core/unrestricted support.

\section{References}

1. Anderson LL, editor. Pigs. 3rd ed: Lea and Fabiger; 1974.

2. Mpofu I, Makuza SMM, editors. Pig Production Science and Technology. UK: Upfront Publishing; 2003.

3. Bangladesh Bureau of Statistics. Report of the household-based livestock and poultry survey 2009. In: Division S, editor: Ministry of Planning, Government of the People's Republic of Bangladesh; 2010.

4. Heitzman J, Worden R. Bangladesh a country study. Washington: GPO for the Library of Congress. 1989.

5. World Population Review. Bangladesh Population 2019. http://worldpopulationreview.com/countries/bangladesh-population/

6. Barakat A, Halim S, Poddar A, Badiuzzaman M, Osman A, et al Socio-economic Baseline Survey of Chittagong Hill Tracts. Dhaka, Bangladesh: Human Development Research Center; 2009.

7. Dhamai BM, editor Migration and Indigenous People: A Perspective of Bangladesh. Expert Workshop on Indigenous Peoples and Migration. Geneva. 2006

8. Nahar N, Uddin M, Sarkar RA, Gurley ES, Uddin Khan MS, et al Exploring pig raising in Bangladesh: implications for public health interventions. Vet Ital. 2013; 49: 7-17.

PubMed: https://pubmed.ncbi.nlm.nih.gov/23564585/

9. Khan SU, Salje H, Hannan A, Islam MA, Bhuyan AA, et al. Dynamics of Japanese encephalitis virus transmission among pigs in Northwest Bangladesh and the potential impact of pig vaccination. PLoS Negl Trop Dis. 2014; 8: e3166

PubMed: https://pubmed.ncbi.nlm.nih.gov/25255286/

10. Erlanger TE, Weiss S, Keiser J, Utzinger J, Wiedenmayer K. Past, present, and future of Japanese encephalitis. Emerg Infect Dis. 2009; 15: 1-7. PubMed: https://pubmed.ncbi.nlm.nih.gov/19116041/

11. Solomon T. Control of Japanese encephalitis-within our grasp? N Engl J Med. 2006; 355: 869-871.

PubMed: https://pubmed.ncbi.nlm.nih.gov/16943399/

12. Haider N, Khan MSU, Hossain MB, Sazzad HMS, Rahman MZ, et al. Serological evidence of hepatitis $\mathrm{E}$ virus infection in pigs and jaundice among pig handlers in Bangladesh. Zoonoses Public Health. 2017; 64: 572-577. PubMed: https://pubmed.ncbi.nlm.nih.gov/28670851/ 
13. Rahman MS, Nuruzzaman M, Ahasan MS, Sarker RR, Chakrabartty A et al. Prevalence of brucellosis in pigs: the first reprot in Bangladesh. Bangladesh J Vet Med. 2012; 10: 75-80.

14. Sardar SADCAKHAI. Helminthiasis in the pigs of Rangamati district of Bangladesh. Eurasian J Vet Sci. 2012; 28: 233-236.

15. Islam A, Anisuzzaman, Majumder S, Rabbi AKMA, Hossain MM. Prevalence and pathology of helminth Infections in pigs. Pak J Sci Industrial Res. 2008; 51: 317-322.

16. Anower AKM, Ahmed MM, Rahman MM, Hasan A, Islam MA, et al. Hygienic farming system improved pig-rearers livlihood statud in SouthWest region of Bangladesh. Int J Avian Wildlife Biol. 2017; 2: 00025.

17. Motsa'A JS, Defang HF, Keambou CT. Socio-economic and technical characteristics of pig (Sus scrofa domesticus) production system in the humid forest with monomodal rainfall agro-ecological zone of Cameroon. Int J Biol Chem Sci. 2018; 12: 2318-2327.

18. Maharjan KL, Fradejas CC. A Study of the Problems Confronting the Backyard Pig Raisers in Batangas Province of Southern Luzon. J Rural Prob. 2005; 41: 236-241.

19. Mekuriaw $Y$, Asmare B. Assessment of Pig Production and Constraints in Mecha District, Amhara Region, Northwestern Ethiopia. Advances in Agriculture. 2014; 2014

20. Toppo A, Rahman MR, Ali MY, Javed A. Socio-economic Condition of Plain Land Tribal People in Bangladesh. Social Sciences. 2016; 5: 58-63.

21. Khanum R, Mahadi MSA, Islam MS. Tribal womens involvement with pig farming in Bangladesh: an evidence of Moulvibazar district. SAARC J Agricul. 2018; 16: 115-127.

22. Umeh JC, Ogbanje C, Adijo MA. Technical Efficiency Analysis of Pig Production: A Sustainable Animal Protein Augmentation for Nigerians. J Advan Agricul Technol. 2015; 2: 19-24.

23. Ritchil $\mathrm{CH}$, Faruque MO, Tabassum F, Hossain MM, Bhuiuyan KFH Socio-economic status of pig rearers and managementsystem of native pigs in Bangladesh. Indian J Animal Sci. 2013; 83: 1226-1228.

24. Nice Foundation. Securing the livelihood through improvement of Kawra/pig-rearing community of southwest Bangladesh. http://www. bluegoldbd.org/innovationfund/project-examples/hygienic-pig-rearing/.

25. Joshi DD, Moller LN, Maharjan M, Kapel CM. Serological evidence of Trichinellosis in local pigs of Nepal. Vet Parasitol. 2005; 132: 155-157.

26. Prakash A, Kumar GS, Rout M, Nagarajan K, Kumar R. Neurocysticercosis in free roaming pigs - a slaughterhouse survey. Trop Animal Health Produc. 2007; 39: 391-394.

27. Prasad KN, Prasad A, Gupta RK, Pandey CM, Singh U. Prevalence and associated risk factors of Taenia solium taeniasis in a rural pig farming community of north India. Transactions of the Royal Society of Tropical Medicine and Hygiene. 2007; 101: 1241-1247. PubMed: https://pubmed.ncbi.nlm.nih.gov/17603090/

28. Prasad KN, Verma A, Srivastava S, Gupta RK, Pandey CM, Paliwal VK. An epidemiological study of asymptomatic neurocysticercosis in a pig farming community in northern India. Trans R Soc Trop Med Hyg. 2011; 105: 531-536
29. Yu H, Zhou Y, Li G, Zhang G, Liu H, Yan L, et al. Further evidence for infection of pigs with human-like H1N1 influenza viruses in China. Virus Res. 2009; 140: 85-90.

PubMed: https://pubmed.ncbi.nlm.nih.gov/19063926/

30. de Jong J, Smith D, Lapedes A, Donatelli I, Campitelli L, Barigazzi G, et al. Antigenic and Genetic Evolution of Swine Influenza A (H3N2) Viruses in Europe. J Virol. 2007; 81: 4315-4322. PubMed: https://pubmed.ncbi.nlm.nih.gov/17287258/

31. Patr MK, Begum S, Deka BC. Problems and Prospects of Traditional Pig Farming for Tribal Livelihood in Nagaland. Indian Res J Extension Education. 2014; 14: 6-11.

32. Ahmed K, Ahmed N, Kalita D, Barman D. Housing practices for small scale pig production in rural communities of Assam. Int $\mathrm{J}$ Chem Studies. 2017; 5: 519-521.

33. Rahman S, Barthakur S, Kalita G. Pig production and management system in Aizawl District of Mizoram, India. Livestock Research for Rural Development. 2008; 20.

34. Wang JP, Kim JD, Kim JE, Kim IH. Amino acid digestibility of single cell protein from Corynebacterium ammonia genes in growing pigs. Animal Feed Sci Technol. 2013; 180: 111-114.

35. Lemke U, Kaufmann B, Thuy LT, Emrich K, A. VZ. Evaluation of smallholder pig production system in North Vietnam. Agricul Sys. 2006; 96: 207-223.

36. Peter G, Jackson G, Cockcroft PD. Handbook of Pig Medicine. New York, USA: Elsevier Science Inc.; 2007.

37. Islam A, Majumder S, Anisuzzaman, Rabbi AKMA, Rahman MS, et al. Prevalence and pathology of ticks and lice of pigs in realtion to age and management systems in Bangladesh. Int J Biores. 2006; 1: 22-27.

38. Ayoade GO, Adejinmi JO, Abiola JO, Lucas F. Efficacy of some anthelmintics used in procince prac tice in Ibadan, Nigeria. African $J$ Biomed Res. 2003; 6: 109-110.

39. Islam A, Singa AK, Majumder S, Anisuzzaman A, Rabbi AKMA, et al. Comperative efficacy of anthelmintics against helminth parasites of pigs. Int J Biores. 2006; 2: 35-41.

40. Garten RJ, Davis CT, Russell CA, Shu B, Lindstrom S, et al. Antigenic and genetic characteristics of swine-origin $2009 \mathrm{~A}(\mathrm{H} 1 \mathrm{~N} 1)$ influenza viruses circulating in humans. Science. 2009; 325: 197-201. PubMed: https://www.ncbi.nlm.nih.gov/pmc/articles/PMC3250984/

41. Gray GC, Trampel DW, Roth JA. Pandemic influenza planning: shouldn't swine and poultry workers be included? Vaccine. 2007; 25 : 4376-4381.

PubMed: https://www.ncbi.nlm.nih.gov/pmc/articles/PMC1939697/

42. Meseko C, Globig A, ljomanta J, Joannis T, Nwosuh C, et al Evidence of exposure of domestic pigs to Highly Pathogenic Avian Influenza H5N1 in Nigeria. Scientific Reports. 2018; 8: 5900.

43. Li H, Yu K, Yang H, Xin X, Chen J, et al. Isolation and characterization of H5N1 and H9N2 influenza viruses from pigs in China. Chinese $J$ Prevent Vet Med. 2004; 26: 1-6.

44. Cyranoski D. Birdflu spreads among Java's pigs. Nature. 2005; 435: 390 